\title{
The Conspiracy and Tragedy of Charles Duke of Byron: The Evaporation of Honour
}

Patricia Demers

... see in his revolt how honour's flood

Ebbs into air, when men are great, not good. ${ }^{1}$

Charles de Gontaut, Duke of Byron, is no reincarnation of Bussy D'Ambois. The superficial similarities he bears to Chapman's earlier hero only serve to outline more clearly the distance between them. The Prologue awards him the status of an autumnal star (1.12) and a fanfare of loud music (I. ii) announces his entrance - so unlike the posthumous stellification and quiet choric self-introduction of Bussy. Byron approaches the discontented La Fin, "alone, and heavy countenanc'd" (II. i. 54), in a way reminiscent of Monsieur's approach to Bussy, just as La Fin's description of the chaotic influence of the moon (III. i. 6-16) recalls the lunar control of Monsieur's imagistic delineation of Bussy's "great heart" (Bussy D'Ambois, I. ii. 138-146). But in The Conspiracy the roles of victimizer and prey are reversed, and the mention of the moon is not part of an ominous encomium but of an admitted lure. It is Byron who is played upon when he commiserates with La Fin as surely as it is he who falls the victim of this Machiavel's "feigned passion" (III. i. 1). His heroic vaunts about leaving his statue eternally rooted on a mountain (III. ii. 141-55), ${ }^{2}$ being a "law rational" (III. iii. 145), and filling his sails "with a lusty wind" (III. iii. 136) are quite removed from Bussy's marbled death stance as "a Roman statue" (V. iii. 144), his defense of that kingly prerogative to "do a justice which exceeds the law" (III. i. 199), and his humble reliance on (or appearance as) a virtuous guide to prevent "shipwreck in our safest port" (I. i. 33). The Tragedy casts Byron's pronouncements in an even less sympathetic light. Unlike Bussy's eventual joining with Hercules (V. iii. 270) and his rugged stand as a box-tree (IV. i. 85), Byron appropriates the Atlas-like role of Hercules (III. i. 151) and considers himself a lofty and unbeaten "cedar on Mount Lebanon" (V. iii. 13) disdaining the box-tree lowliness of his judges. But, as Henry remarks, Byron's eventual port is only "despair and ruin" (III. ii. 69), and, in Epernon's view, his outcome is a disappointment of previous stellar potential, comparable to "An exhalation that would be a star ... which fell, when the sun forsook it, in a sink" (IV. ii. 292-3). Selfpitying hyperbole seems to dominate his conclusion that "virtue in great men must be small and slight, / For poor stars rule where she is exquisite" (V. ii. 186-7) and hence to distinguish it also from the detached choric utterance of Monsieur about the fate of "this full creature (who) now shall reel and fall" (Bussy D'Ambois, V. iii. 46). Although similar features, such as a shared encomiastic treatment of Elizabeth, outbursts of viciousness, riddles, chess games, and forms of choric commentary, may appear to link the plays more closely together, in reality such similarities separate them even more. While Bussy's King praises Elizabeth's court, Byron's King proposes an educative sojourn there to calm his splenative Duke (III. ii. 274-84). The viciousness of the honest assessments which Bussy and Monsieur engage in resides wholly in verbal power; in contrast, the revelation of $\mathrm{La}$ Brosse $^{3}$ adds to the tension of The Conspiracy by unleashing the Duke's physical rashness and extracting his confession about a pitiful preference of flattery, so foreign to the searing truth of Bussy's encounter with Monsieur. The riddle of the easily won Pero about 
chastity is fitting to the information she offers in Bussy D'Ambois yet far removed from the equally appropriate riddle of good fame which the masquers present in The Tragedy of Byron. While Henry III and the Guise are playing chess at the time of Bussy's noticeable initiation at court, Henry IV proposes "a battle at the chess" (IV. ii. 95) to the fiery Duke as a prelude to his arrest for treason. Though the chorus of Guise and Monsieur underscores the tragic irony of fullness and solidity, the observations of Epernon which recount "of what contraries consists a man!" (Tragedy, V. iii. 189) seem more tailored to the fluctuations and paradoxes of character which have created Byron's tragedy. Both worlds are "quite inverted" (Tragedy, I. ii. 14), but the reader might find the inversions which account for the tragedy of Byron to be self-created, explicable, and distinct from the external and inscrutable forces which appear to dominate Bussy's universe.

If these inversions seem intelligible, however, the images which depict Byron's status and dilemmas seem more compacted than those of Bussy D'Ambois. Although their picturing power still makes them generally emblematic, they function more as part of a deliberate cluster and less as independent images. The Prologue itself provides an example of such an imagistic conglomerate and also introduces one of the key metaphors of Chapman's play. Just as the wealthy autumnal star, having been "Wash'd in the lofty ocean, thence ariseth, / Illustrates heaven, and all his other fires / Out-shines and darkens" (II. 13-15), Byron's rise involves a similarly scintillating ascent to the ocean of the sky. But the thirst for "his country s love" (I. 18) leads him to the empoisoning spring of Policy whose effects reverse inflation into deflation, ascent into descent: "He bursts in growing great, and, rising, sinks" (I. 21)' His flood of honour evaporates, or as Chapman expresses it, "Ebbs into air" as testimony of the outcome "when men are great, not good" (1. 24). In addition to its warning about the hero's character, such an introduction also indicates the working of an image unit which with varying degrees of lucidity and coherence will reappear throughout The Conspiracy and Tragedy of Charles Duke of Byron.

The sharing of the same lead roles links these two parts together as a single play in an even more remarkable and necessary ${ }^{+}$fashion than $I$ and $I I$ Tamburlaine. In fact, The Conspiracy seems only a prelude to The Tragedy. While Tamburlaine emerges from Part One as an undeniable cosmic power, the only issue of The Conspiracy is the overhasty and indeed tenuous reunion of King and subject, soon to be shattered by the opening lines of The Tragedy. The closest link - actually, the lifeline - between the two parts is the imagery which in The Conspiracy always seems about to receive the final punctuation which The Tragedy ultimately bestows.

Perhaps the image of evaporation contains the keynote for the whole play. It provides Byron, Henry, and the observant Janin with revealingly different explanations. In attempting to calm the "feigned passion" (III. i. 1) of La Fin, Byron uses the simile of the supposedly temperate air:

That evenly interpos'd betwixt the seas

And the opposed element of fire,

At either toucheth, but partakes with neither;

Is neither hot nor cold, but with a slight

And harmless temper mix'd of both th' extremes. (III. i. 42-6)

It seems indicative of Byron's own naiveté that he should consider air remaining harmlessly unaffected when stretched between such extremities as fire and water, heat and cold. In his passage "through things call'd good and bad" (1.41), according to Byron, man is 


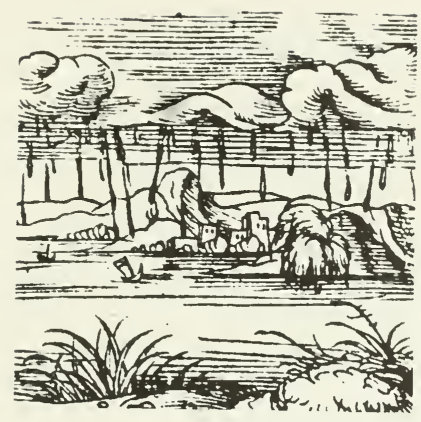

Figure 1

Па $а \zeta \pi \delta \iota \S \epsilon \iota \delta \nu$, from a 1551 edition of Horapollo's Hieroglyphics. Cf. Byron's Tragedy, III. i. 210-11.

similarly untouched; yet his own tragedy testifies powerfully to the contrary. One of the glories of Elizabeth's court and thus of her kingdom is its openness and amplitude, fittingly conveyed as "unbounded as the ample air" (IV. i. 12); and later Henry comments that we can only expect impartial judgement when "the air contain'd within our ears" (V. ii. 58) refrains from "offensive sounds" (1.60) and its own tumult within in order to perceive and moderate "differences without them" (1.66). Although in The Tragedy even La Fin cautions Byron to "give temperate Air / To his unmatch'd and more than human wind" (I. ii. 44-5), the Duke's rashness and its resultant criminality prevail and reach their drizzling $^{5}$ nadir in Janin's observation. Byron's cloud-like eminence (I. ii. 56) as he proudly hawks at kingdoms either evaporates or condenses into an abrupt and inglorious end:

... suddenly, the fowl that hawk'd so fair,

Stoops in a puddle, or consumes in air. (III. i. 210-11)

Such Byronic condensation is surely quite removed from Horapollo's instructive hieroglyph about heavenly learning (Figure 1$)^{6}$

The air that images such an ignominious end also allows for the beginning of deceptive inflation. Flattery can be just as misleading as the heart-deadening accumulation of knowledge which the Lyonese bluestocking, Georgette de Montenay, lamented in her emblem, "Scientia inflat,", for its inflation is as insubstantial and fictionally regressive as Donne's "superficies of air." 8 Recalling the Prologue's image of the man who "bursts in growing great" (1. 21), Henry cautions Byron against a credulous acceptance of the "empty breath" (III. ii. 259) and "passions of wind" (1.260) of hired flatterers. The praises they bestow, like the empty vaunts of the eulogistic verses prefacing a volume of poetry," are worthless; in Henry's deprecation (which could also be a backhanded compliment for Byron), they are "fitter to blow up bladders than full men" $(1.266)$. The foremost reason why Byron has such a difficult time convincing his audience of the rightness of his cause resides in the calm, sagacious, and deservedly respected figure of Henry IV. The King's 
wisdom throws his subject's spleen into unflattering relief. Henry remains undaunted in his efforts to convince Byron of the false inflation of flatterers:

.... who in swelling

Your veins with empty hopes of much, yet able

To perform nothing, are like shallow streams

That make themselves so many heavens to sight. (V.ii. 69-72)

This monarch goes as far as to suggest the remedy of deflation, to "pierce them to the very earth" (1.78), and graciously extends a clement yet curt invitation to "leave them and be true to me / Or you'll be left by ali" (11.79-80). Following the King's condemnation of him as "an atheist ... and a traitor / Both foul and damnable" (Tragedy, IV. ii. 250-1), Byron's reaction of injured innocence is hardly credible. He pictures himself as an abused anvil, "the seed and wombs of others' honours" (1.272), and the slave of a tyrannical bellows, "A property for a tyrant to set up / And puff down with the vapour of his breath" (11.273-4). Significantly, now that his once-clandestine anvil is no longer "lin'd with wool" (Tragedy, I. ii. 54), Byron has still to realize the identity of the harmoniously flattering blacksmith who has inflated his own bellows. This frenzied metaphor of the accused is both predictably misinformed and damningly revealing.

The two elements found in the Prologue, air and water, afford workable analogues for Byron's tragedy. Just as the air which stretches to heaven yet holds evaporated honour, the water can form a flood yet also ebb into air. The flow of smaller into larger bodies of water is a central image for it does more that illustrate the play's chain of command; it depicts a threat as constant as evaporation - envelopment. Savoy uses this image to describe the position of the newly exiled La Fin, likened to a greedy little river, in face of his King, who is the roaring devouring sea (I. i. 183-192). Later he uses the image of "a little brook being overrun/ With a black torrent" (II. ii. 188-9) to taunt Henry in a different way about the defeat of the rebellious Du Maine at the hands of the singularly superior torrential force of Byron. Henry counters with his comparison of Byron to "the wild and slippery element" $(1.234)$ in water which is carried in open vessels and prevented from overflowing by the presence of "treen cups" (1.233), comparable to the Duke's assistance by Colonel Williams, who "Swum in Byron, and held him but to right" (1.238). Indicative of the unhealthy surreptitiousness of his policy for gaining support, Byron suggests that he winds about his prospects "like a subtle river" searching for "the easiest parts of entry on the shore" (III. i. 68, 71). He seems more of a forecasting of Webster's Flamineo who would be as "engaged to mischief . . . / As rivers to find out the ocean"10 and less of an example of a nationally admired Duke. Imperceptive as well, he proposes joining his stream with La Fin's (1.75) and openly warms to this piece of Savoy's questionable geography and purposeful obsequiousness: "All honours flow to me, in you their ocean" (III. ii. 24). Byron's torrential pride is easily harnessed to feed the subtle streams of Savoy and La Fin. As the Duke previews his mountain statue, his description of one particular feature makes clear the successful manipulation of his flatterers; interestingly, this comparison recalls the earlier position of Savoy himself:

I'll pour an endless flood into a sea

Raging beneath me, which shall intimate

My ceaseless service drunk up by the King,

As th' ocean drinks up rivers and makes all

Bear his proud title (11 $170-74)$ 
But Byron's bruised pride cannot match the politic guile and elasticity of Savoy's volteface, as he turns his "streams another way" (1.196) at the entry of the King's nobles, Nemours and Soissons.

The full extent of Byron's victimization becomes apparent in The Tragedy wherein he attempts to justify himself from a standpoint noticeably different from the confident and lofty height of his envisioned statue. No longer is he the nutritive source but the inundated "Stygian flood" (IV. i. 62) whose enemies are attempting to drown in itself. The very rivers who have fed him and are hiding in his seas, "since their deserts / Are far from such a deluge" (11.63-4), are trying to flood him by denouncing him to the King. Turbid though his metaphorical justification may be, it is an incomplete explanation of his position as victim, for it exonerates the principal victimizer. As he mounts the scaffold, he uses the image one last time in delivering his comments on death, a compendium of pitiable narcissism and willful blindness. Apparently this traitor considers himself one "Whose ends will make him greatest, and not best" (V. iv. 145) - predictably superlative extensions of the Prologue's epithets. He advises those about him to "imitate streams, / That run below the valleys and do yield / To every molehill" (11. 152-4). Yet despite such compliant yielding, these streams evidence an unsettling reaction to torrents which have previously been compared to Byron's force:

... when torrents come,

That swell and raise them past their natural height,

How mad they are, and troubled! (11.155-7)

Then Byron seems to reverse the attractiveness of the streams and the uproar of the torrents by concluding with this puzzling view of kingship:

... Like low (streams)

With torrents crown'd, are men with diadems. (11.157-8)

These frenetic images mirror their speaker and outline the appalling extent of his selfvictimization.

Along with the images depicting the flow of rivers and currents, specifically marine imagery also appears. Like the vastness of the body of water it describes, this sea imagery usually denotes the greatness - genuine, proposed, or illusory - of its speaker. The exiled La Fin's boast which he enjoins Byron to carry to his King is a significant recasting of the Prologue's praise of the Duke as an autumnal star "in the lofty ocean" (1.13). La Fin's promise "to lift the sea/ Up to the stars" (Conspiracy, III. i. 119-20) begins his account of paradoxical future feats which closes with this noteworthy blend of ranting anarchy and flunking logic:

... to dissolve all laws

Of nature and of order, argue power

Able to work all, I can make all good. (11.125-7)

Surely such raving reflects just as unfavourably on La Fin's impossible yet envenomed plans for vindication as it does on the ease with which his imperceptive interlocutor is duped into supporting him, to "put off from this dull shore of (ease) / Into industrious and high-going seas" (11.149-50). True, the Duke is awarded flattering plaudits about his sea-going abilities. For Henry's benefit, Savoy pictures Byron "on his brave beast Pastrana" sitting "like a full-sail'd Argosy / Danc'd with a lofty billow" (II. ii. 67-9), and later, still for Henry's edification, describes the battle deeds of this superior subject by attributing to such a warrior Peacham's virtue of "manlie constancie,"11 as he breaks his enemies 
"like billows 'gainst a rock" (1.131). Byron himself is quite adept at previewing his own marine activities; the endless flood pouring from his statue will feed a supposedly voracious kingly sea to indicate his "lasting worth" (III. ii. 176), while, following La Brosse's unhappy revelation, his forced exuberance about untrussing the slaveries of "all worthy spirits" (III. iii. 130) takes the form of setting out on "life's rough sea" with "his sails fill'd with a lusty wind" (11.135-6). He proceeds to outline the perils similar to those endured by Peacham's storm-tossed galleon; ${ }^{12}$ the description of "his rapt ship run on her side so low / That she drinks water, and her keel plows air" (11.138-9) merely prefaces his confident pronouncement ${ }^{13}$ that "there is no danger to a man that knows / What life and death is" (11. 140-1). But there is a great difference between proposing marine activities and actually "being a sea" (IV. i. 30), just as there can be as much danger as grandeur in being "a mighty promontory" (1.190). Elizabeth's speech seems to contain the sobering antidote for Byron's projected eminence. In addressing her visitor, she draws a comparison between a vast, overhanging, but eroded promontory and those corrupted great ones who by "building out / Too swelling fronts for their foundations, / When most they should be propp'd are most forsaken" (11.196-8). But her advice evidently goes unheeded for The Tragedy not only recalls the "turbulent sea" (I. i. 117) of civil war but also focuses finally on the rude tumult of Byron's own uncalm sea (V. iv. 203-4).

Although this play does not appear to move through a series of tableaux in the same fashion as Bussy D'Ambois, it creates its own aura of the stately presence and political confrontations which coexist almost expectedly in courts and embassies. Utilizing such a backdrop, The Conspiracy presents two outstanding pictures at its exhibition of Byron. Both deserve the name hieroglyphics, as, with true pictographic and moral ardour, they interpret their sights as signs of Byron's quixotic potential. Savoy's picture of the Duke on his horse easily becomes a Golden Age recasting:

They do the best present the state of man

In his first royalty ruling and of beasts

In their first loyalty serving. (II. ii. 72-4)

Neither duress nor subjugation inheres in this idyllic situation, only willing co-operation. The speaker loses no time in elevating his picture to the status of "a doctrinal and witty hieroglyphic / Of a blest kingdom" (11. 78-9), particularly significant in terms of the lesson it bluntly delivers to its royal audience:

... to express and teach

Kings to command as they could serve, and subjects

To serve as if they had power to command. (11.79-81)

Though Henry's unventuresome comment about Savoy's wit "That can make anything of anything" (1.85) signals this pupil's adroit halt to his lesson, Savoy's hierogly phic has been an aptly timed and strangely revealing device. ${ }^{14}$ Though his description began with Byron as the kingly rider, it closes not only with the suggestion of Henry as rider but also, and more importantly, with the impossibly ideal intimation of the interchangeability of bearer and rider. The mental picture it suggests recalls Whitney's comparable emblem (Figure 2) in praise of Sir Philip Sidney, who by virtue of being one of those "men of judgement graue, / Of learning, witte, and eeke of conscience cleare" 15 controls his tramping steed; interchangeability would be as inapt here as it is fitting in Chapman's context. In addition to its appropriateness as a political figuration, Savoy's hieroglyphic provides a subtle yet strong base for his purposeful insinuations to Henry about his subject's inflating pride. 


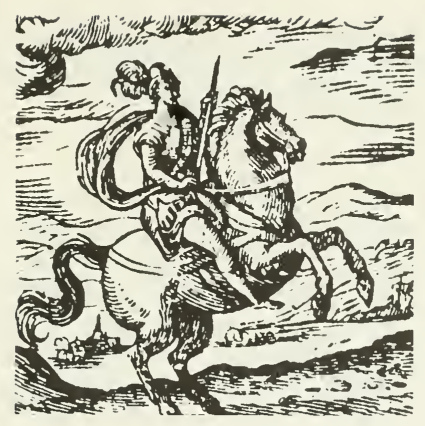

Figure 2

"Non locus vir, sed vir locum ornat," from Whitney's Choice of Emblemes, p. 38. Cf. Byron's Conspiracy, II. ii. 67-81.

Elizabeth's speech contains the second hieroglyphic which also delivers a lesson, but one specifically designed to benefit her French visitor. Having explained the analogy between the eroded promontory and corrupted men, she concludes her teaching with a description of the heavens as "Aperfect hieroglyphic to express / The idleness of such security" (IV. i. 207-8) as that provided by the apparent sturdiness of the promontory. She supports "the grave labour of a wise distrust, / In both sorts of the all-including stars" (11.209-210) by clarifying how the appearance of the stars to the earth-bound observer need not indicate their astronomical position: "The fixed stars waver, and the erring stand" (1.213). Twinkling results not from movement but fixity, while steady shining emanates from erring or wandering planets. ${ }^{16}$ Perhaps her lesson is either too direct or too obscure, for, while he admits that "the stars / . . are divine books to us" (11.216-7), Byron politely dismisses the Queen's counsel with the confident assessment, "I need it not" (1.220). However, when he faces the condemnation of the Chancellor, Byron shows how much he was in need of such advice, for all he now can rely on is a sacrilegiously self-appropriated acquittal from God. The basis for such a vindication is his tragically unsound view of himself as one of God's "truest images" (Tragedy, V. iii. 100).

With this tragedy, in particular, the reader is quickly impressed by the amount of natural analogues and the ease with which they work. Such correspondences find their best explanations in extended image units, in agglomerations like those describing the hieroglyphics. Perhaps the most outstanding is Byron's account of the effects of the self-exiled Duke d'Aumale's treason. As d'Aumale was fleeing France, he

... had his statue torn

Piece-meal with horses, all his goods confiscate,

His arms of honour kick'd about the streets,

His goodly house at Annet raz'd to th' earth,

And (for strange reproach of his foul treason)

His trees about it cut off by their waists. (Conspiracy, I. ii. 148-53) 
The ducal narrator, full of the integrity of a loyal subject at this point, carefully adduces a series of moral positions to explain each of these justifiable assaults against traitors:

To seek without them that which is not theirs,

The forms of all their comforts are distracted,

The riches of their freedoms forfeited,

Their human noblesse sham'd, the mansions

Of their cold spirits eaten down with cares,

And all their ornaments of wit and valour,

Learning, and judgement, cut from all their fruits, (11. 158-64)

Tree analogues are especially prominent. In addition to this concluding correspondence, Byron later prefaces his enquiry at the house of the astrologer with an observation about the doom that awaits fortunate men who, "like trees that broadest sprout, / Their own too top heavy state grubs up their root" (III. iii. 29-30). The Tragedy traces the distance Byron moves away from his initial stand and the growing inevitability of his second. The King and his infant heir are left to defend their own "tree of rule" and to cut from it "all trait'rous branches" (I. i. 113), for, while Byron laments the withering of the "goodly tree" (III. i. 27) of religion, a scion from the no longer vital tree of empire, he also proposes to be a hardy weather-beaten "blackthorn" (1.127) and a loftily pristine "cedar on Mount Lebanon" (V. iii. 13). However, despite their box-tree lowliness, his judges manage to reduce his proud eminence with awesome finality. Following the Prologue's example, stars provide a workable analogue too. Although La Brosse indicates the curious difference separating the ignorant yet fatal stars from sapient yet helpless men (III. iii. 5-8), his reckless client assumes that he is "a nobler substance than the stars" (1.109), and continues with this arrogant clarification:

I have a will and faculties of choice,

To do, or not to do: and reason why

I do, or not do this: the stars have none;

They know not why they shine, more than this taper. (11.112-15)

Epernon's later comments on Byron's unfulfilled stellar potential (Tragedy, IV. ii. 291-5), though, bring proposals of superiority and treasonous actions into closer alignment, while Byron's self-protective righteousness about the "envious stars" (V. ii. 203) of his accusers remains a pathetically inadequate ploy. Clouds also run an analogue gamut, extending from the thoughtful adjuration of Picoté to the unwilling involvement of Byron. Although Picoté advises the admittedly superior Duke to avoid destroying himself by adopting an emblematic ${ }^{17}$ position (Figure 3 ) of unsullied height, "Like those steep hills that will admit no clouds, / No dews, nor least fumes bound about their brows, / Because their tops pierce into purest air" (Conspiracy, I. ii. 104-7), Byron's tragedy is proof either of the inadequacy of his height or of the susceptibility of his lowness. When imprisoned, he wishes to escape his uncertain status as a cloud, but despite his visions about "recovering heat and lightness' and being "by the sun / Made fresh and glorious" (Tragedy, V. iii. 46-8), his re-ascendancy is not only doubtful: it remains impossible.

Earlier when Byron had considered how "immortal" it would be "to die aspiring" (Conspiracy, I. ii. 31), he cited the example of "happy Semele" / That died compress'd with glory!" (11. 37-8); and before his execution he makes the claim to have been "Like Orpheus casting reins on savage beasts" (Tragedy, V. ii. 10). Such extravagant boasts must cause the reader to question both the perceptiveness and the credibility of this Chapman hero. As surely as Faustus recognized a difference between happy and hapless Semele,"18 


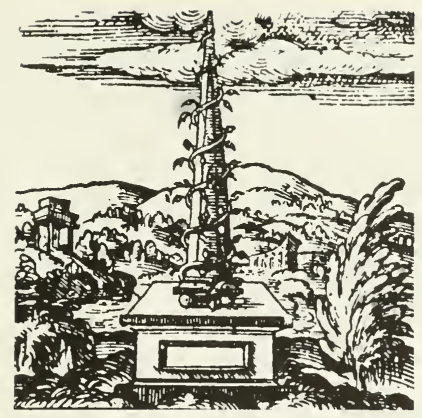

Figure 3

"Te stante, virebo," from Whitney's Cboice of Emblemes, p. 1. Cf. Byron's Conspiracy, I. ii. 104-7.

there would seem to be a comparable expanse separating the fanfare of Byron's supposedly Orphic skills from the quietly circular suasiveness of Whitney's emblem (Figure 4) celebrating "Orpheus with his harpe, that savage kinde did tame."19 And, if his boasts seem wide of the truth, so also do his logical powers seem wanting. It is in the least foreboding to hear a protagonist declare about Fortune that "I will win it though I lose my self" (Conspiracy, II. i. 146), and far from indicating ameliorative intent when, in talking of the country he has repaired, such a hero vows to "ruin it again to re-advance it" (Tragedy, 1. ii. 35). Yet Byron's deficiencies have not eluded hisKing. Henry announces early enough that his subject has been surpassed in terms of experience and brain (Conspiracy, Il. ii. 219), and diagnoses that Byron's "adust and melancholy choler" (1.43) warrants the prescription of "temperate English air" (1.49). Yet temperance never seems to be associated with Byron. Rather, from his first to his final appearance, the rashness of a chamelon temperament and the ineffable hauteur of the self-destructive overreacher seem to characterize his behaviour. Despite its predictability, one senses the tragic waste when the

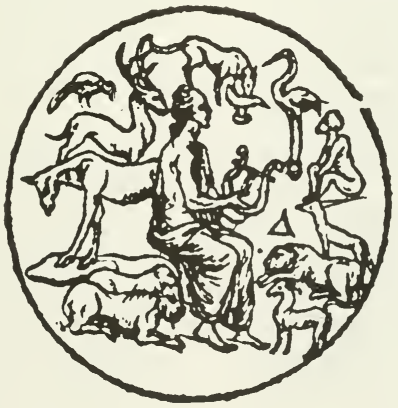

Figure 4

"Orphei Musica," from Whitney's Choice of Emblemes, p. 186. Cf. Byron's Tragedy, V. ii. 10. 
Duke, who had previously argued that "To have stuff and form, / And to lie idle, fearful, and unus'd, / Nor form nor stuff shows" (Conspiracy, I. ii. 35-7), meets the "decretal end" (Tragedy, V. iv. 229) of his death. His form has been blasted, his cannon outshot, his stuff abused. Furthermore, his final sermon ${ }^{2)}$ relies on his own negative example to preach the worthlessness of once-prominent statues (11.254-5). Yet, in his own inimitable "Byronic" manner, Chapman allows flashes of inconsistency to mar such penitence and thus to hinder the resolution of his hero's puzzle. On the scaffold this traitor enjoins his relatives "To keep their faiths that bind them to the King" (1.233), and the man Henry has condemned as an atheist commands his soul to "Bear the eternal victory of Death" (1. 261). The spectrum of diverse critical views ${ }^{21}$ that such a creation has provoked, varying from outright condemnation to a realization of this foreseeable tragedy with a difference, are not entirely surprising; for, as my examination of its imagery has attempted to illustrate, a play in which heroic vaunt evaporates pitifully and word and deed oppose one another so palpably, continues to exercise the attraction of a puzzling certainity.

The University of Alberta

\section{Notes}

1 "Prologue," 11.23-4, The Conspiracy and Tragedy of Charles Duke of Byron, The Plays of George Chapman: The Tragedies (1914; rpt. New York: Russell \& Russell, 1961). All subsequent references to the tragedies will be based on this edition, with the exception of Bussy D'Ambois, ed. N. Brooke (London: Methuen \& Co. Ltd., 1964).

2 Millar MacLure aptly comments on Byron's "giantism prefiguring the meglomania of Mount Rushmore," George Chapman: A Critical Study (Toronto: University of Toronto Press, 1966), p. 139. In his doctoral thesis, "The Animate Glass: Chapman's Dramatic Evolution" (Diss. University of Rochester, 1964), James E. Parsons threads his theme of destructive posture into this obserfation: "Byron's hallucinatory mental statuary is the master builder of the self-destructive monuments of pose" (p. 317).

3 Johnston Parr cites several popular booklets to validate his contention that "everyone learned in astrological lore in Chapman's day knew that a malignant Caput Algol in one's horoscope presaged one's decapitation," in his article "The Duke of Byron's Malignant 'Caput Algol'," SP, 43 (1946), 198.

4 Not a subscriber to the view of Tamburlaine as a ten-act moral play which Roy
Battenhouse advances in his book Marlowe's Tamburlaine: A Study in Renaissance Moral Philosopby (Nashville: Vanderbilt University Press, 1941), I prefer the structural analyses of distinct parallels and differences between $I$ and $I I$ Tamburlaine which are the concerns of G.I. Duthie, "The Dramatic Structure of Marlowe's 'Tamburlaine the Great,' Parts I and II," ES, 1(1948), 101-126; and Clifford Leech, "The Structure of Tamburlaine," $T D R, 8(1964), 34-46$.

5 L. C. Stagg points out how Byron, "the once proud cloud, drizzles himself ignominiously out of existence," in his article "Characterization Through Nature Imagery in the Tragedies of George Chapman," Ball State University Forum, 9(1968), 43.

6 D. J. Gordon explains that in composing his Hieroglyphica Valeriano borrowed Horapollo's image of dew falling and extended it into a distinction "between profane learning (Doctrina gentium) which is like bitter waters that bring forth no fruit and heavenly learning (Doctrina Coelestis) which brings forth much fruit." He offers this explanation along with a copy of Horapollo's hieroglyph in his article "The Imagery of Ben Johnson's The Masque of Blackness and The Masque of Beautie," JWCL, 6(1943), 126, 136. 
7 Robert J. Clements quotes from Emblèmes, ou devises chrestiennes (Lyon, 1571), p. 87, Picta Poesis: Literary and Humanistic Theory in Renaissance Emblem Books (Roma: Edizioni Di Storia E Letteratura, 1960), p. 71; one line in particular of de Montenay's accompanying verse, "Ouvre le sens \& le coeur mortifie," is much in the spirit of Chapman's later deprecation of walking dictionaries, Euthymiae Raptus, 1. 531.

8 Donne considers the transience of time and place with this airy ramification: "How thin and fluid a thing is air, and how thin a film is a superficies, and a superficies of air! ," XIV. Meditation, Devotions Upon Emergent Occasions Together With Death's Duel (Ann Arbor: University of Michigan Press,1959), pp. 88-9.

9 See Parrott's note, Tragedies, 11, 606.

10 John Webster, The White Devil, I. ii. 335-6, Jobn Webster and Cyril Tourneur: Four Plays, ed. J. A. Symonds (New York: Hill and Wang, 1956).

11 Henry Peacham, "Nec igne, nec unde," Minerva Britanna 1612, A Scolar Press Facsimile (Leeds: The Scolar Press, 1966), p. 158.

12 Peacham, "His graviora," Minerva Britanna, p. 165 .

13 In The Jacobean Drama: An Interpretation (London: Methuen \& Co. Ltd., 1936), Una Ellis-Fermor explains the "defiance and tension" of Byron's speech as "the measure of Chapman's resistance to the fatalism more common in his age" (p. 64); however, she concludes that this hero must fall in the face of "Chapman's stern sense of public responsibility and knowledge of the instability of human fortune" (pp. 65-6).

Parrott notes that Shelley chose lines 140-143 as the motto for his Laon and Cytbna, Tragedies, II, 607.

14 Rosemary Freeman calls this passage (II. ii. 66-81) "a speaking picture" with "its interpretation and its moral lesson . . . all present," English Emblem Books (1948: rpt. London: Chatto \& Windus, 1967), p. 6. Clements views Byron and his horse as "symbols of royalty ruling and loyalty serving," Picta Poesis, p. 79. Mario Praz uses Savoy's description as illustrative of Chap- man's "emblematical bias," Studies in Seventeenth-Century Imagery, Second Edition (Roma: Edizioni Di Storia E Letteratura, 1964), p. 220.

15 Geoffrey Whitney, "Non locus vir, sed vir locum ornat, "To The Honorable Sir Phillip Sidney Knight," A Cboice of Emblems, ed. H. Green (London: Lovell \& Reeve Co., 1866), p. 38, 11. 7-8.

16 See Parrott's gloss, Tragedies, II, 608.

17 Though Whitney pictures "A mightie Spyre, whose toppe dothe pierce the skie" (1.1), and not a steep hill, the key notion of loftiness obtains both in the emblematist's figure of the inter-relationship of Church and State and in the Frenchman's simile for Byron's absoluteness. See "Te stante, virebo," $A$ Choice of Emblemes, p. 1.

18 Of course, Faustus's desire of Helen invests his perception with quirks too; he cven admits that this fabled dame is "Brighter ... than flaming Jupiter / When he appeared to hapless Semele," Doctor Faust us, V. i.

114-5, The Complete Plays of Christopher Marlowe, ed. I. Ribner

(New York: The Odyssey Press, 1963).

19 "Orphei Musica," A Choice of Emblemes, p. $186,1.1$.

20 Commenting on what he termed the "classics" of the Byron plays, Algernon C. Swinburne remarks about the "pathos of a high and masculine order in the last appeals and struggles of the ruined spirit and the fallen pride which yet retain some traces and likeness of the hero and the patriot that has been," George Chapman: A Critical Essay (London: Chatto \& Windus, 1875), pp. 92, 95. In his essay "Shakespeare and the Stoicism of Seneca," T. S. Eliot mentions the "conspicuous ... self-dramatization" with which such Chapman heroes as Bussy Byron, and Clermont die; see Selected Essays (London: Faber and Faber, 1932), p. 129.

21 Foremost in the condemning vanguard is Ennis Rees with his views on the wrongness of Byron's cause, his lack of integrity, and his godlessness; see The Tragedies of George Chapman: Renaissance Etbics in Action (Cambridge: Harvard University Press, 1954), pp. 52, 60, 66. John William Wieler earlier defended the position that Byron was "doomed because of discontent," George Chapman - The Effect of Stoicism 
Upon His Tragedies (1949; rpt. New York: Octagon Books, 1969), p. 58.

Several scholars adduce reasons for qualifying Chapman's success in The Conspiracy and Tragedy of Charles Duke of Byron. In An Introduction to Stuart Drama (London! Oxford University press, 1946), Frederick S. Boas finds it overloaded with historical detail (p. 33). When comparing the heroes of Chapman's first two tragedies, Jean Jacquot judges Byron to be more static than Bussy and concludes that he is mainly "un personnage passif dominé par l'orgeuil et manoeuvré par quelques intrigants;" see George Chapman (1559-1634) sa vie, sa poésie, son tbéâtre, sa pensée (Paris: Société D'Editions Les Belles Lettres, 1951), p. 194. In Endeavours of Art (Madison: University of Wisconsin Press, 1954), Madeleine Doran sees "irresolution" as the "fault of the Byron plays" (p. 356). Robert Ornstein laments the victory of morality over drama, while Irving Ribner considers Byron more blackened by sin than Bussy; see The Moral Vision of Jacobean Tragedy (Madison: University of Wisconsin Press, 1965), p. 60, and Jacobean Tragedy, The Quest For Moral Order (London:

Methuen \& Co., 1962), p. 22.

Others, however, have recorded the contradictions and complexities which make Chapman's tragedy engaging fare. Janet Spens was an early praiser of its hero's eminence; her monograph, "Chapman's Ethical Thought," Essays and Studies, 11 (1925), describes Chapman's "greatest creation" as "a soldier of genius" whose personality is on a Titanic scale" and whose hallmark consists of "overflowing vitality" (p. 155). Peter Ure has advanced at least three worthwhile views on separate occasions, in "The Main Outline of Chapman's Byron", SP, 47(1950), he describes Byron as "an Alexandrian hero of corrupted virtue" (p. 571) who also resembles "those Renaissance toys of pleated paper" (p. 568); in "Chapman's Tragedies," Jacobean Theatre, Stratford-upon-Avon Studies, $1(1960)$, he recognizes that this play bursts the "cerements of moralized drama" ( $p$. 229), but he also labels its hero as a "wildfire without a centre" (p. 240); in "A Note on 'Opinion' in Daniel, Greville and Chapman," $M L R, 46(1951)$, he explains that the ruin of Byron lies in his following of opinion (p. 335). At least two other scholars have continued to stress the importance of this tragedy in more recent articles. G. R. Hibbard confidently asserts that it is a better play than Bussy because Chapman's attitude was "more mature and ambivalent," in

"Goodness and Greatness: An Essay on the Tragedies of Ben Johnson and George Chapman," Renaissance and Modern Studies, 11(1967), 41; and Sidney Homan is in agreement, finding that "Chapman's lingering fascination with the superman type" leads to a creation that is more "complex" than Bussy because of its more numerous "contradictions," in "Chapman and Marlowe: The Paradoxical Hero and the Divided Response," JEGP, 68(1969), 392, 405. 